\title{
A Mechanized Determination of Serum Iron Concentration and Iron Binding Capacity with the Beckman Analyzer DSA 560
}

\author{
By R. HAECKeL \\ Institute for Clinical Chemistry Medizinische Hochschule Hannover
}

(Eingegangen am 5. Januar/13. Februar 1973)

\begin{abstract}
A direct bathophenanthroline method was adapted to the DSA 560 (Beckman Instruments) for the mechanized determination of the iron concentration and of the total iron binding capacity in $300 \mu \mathrm{l}$ serum. The reliability of this procedure and the experimental conditions for the binding of $\mathrm{Fe}^{3+}$ ions were investigated. Between 100 and $500 \mu \mathrm{mol} / 1 \mathrm{Fe}^{3+}$ the saturation curve of the total iron binding capacity reached a plateau which approximately correlated with the immunological transferrin concentration. This plateau could not be observed with some commercial control sera.
\end{abstract}

Eine direkte Bathophenanthrolin-Methode wurde an den DSA 560 (Beckman Instruments) zur mechanisierten Bestimmung der Eisenkonzentration und der totalen Eisenbindungskapazität in $300 \mu \mathrm{l}$ Serum adaptiert. Die Zuverlässigkeit dieses Verfahrens und die experimentellen Bedingungen für die Bindung von $\mathrm{Fe}^{3+}$-Ionen an Serumeiweiß wurden untersucht. Die Sättigungskurve der totalen Eisenbindungskapazität erreicht zwischen 100 und $500 \mu \mathrm{mol} / 1 \mathrm{Fe}^{3+}$ ein Plateau, das ungefähr mit der immunologischen Transferrin-Konzentration korreliert. Dieses Plateau konnte bei einigen kommerziellen Kontrollseren nicht beobachtet werden.

In clinical chemistry the serum iron concentration is usually determined by photometric procedures. A direct bathophenanthroline method, which is available as a commercial kit, was adapted to the Discrete Sample Analyzer (DSA) 560, a combined-discrete system (1). A report on the reliability of this mechanized procedure is presented in the light of our experience in its operation.

Usually, the determination of the iron binding capacity is requested parallel with that of the serum iron concentration. Therefore both methods should be mechanized together. For the determination of iron binding capacity all samples are prepared manually. After the addition of $\mathrm{FeCl}_{3}$ to $200 \mu \mathrm{l}$ serum the excess of ferric ions is precipitated with $\mathrm{MgCO}_{3}$ according to RAMSAY (2). The supernatant is introduced into the DSA 560 and analyzed for its total iron concentration.

\section{Materials and Methods}

\section{Instruments}

DSA 560: Beckman Instruments Inc. (USA, Fullerton 92634). Photometer $1101 \mathrm{M}$, Dispenser 5210, Microcentrifuge 5411 (16000 r. p. m.), Rotating Mixer 5431: Eppendorf Gerätebau $\mathrm{GmbH}$ (D-2 Hamburg).

\section{Materials}

Merckotest No. 3307 and No. 3313 are purchased from E. Merck AG (D-61 Darmstadt), iron wire from Riedel-de-Haen AG (D-3016 Seelze), $\mathbf{M g C O}_{3}$ from J. T. Baker Chemicals N. V. (NL-Deventer), bovine albumin (purest) from Behringwerke AG (D-355 Marburg), Seronorm from Dr. Molter GmbH (D-69 Heidelberg), Monitrol from Merz and Dade (D-8 Munich), polypropylene reaction cups (Nr. 39/10 A) and monovettes for blood sampling (Nr. $950 \mathrm{RA}$ ) from W. Sarstedt (D-5223 Nümbrecht) and Q-cups (US-type, Nr. 5206) from Beckman Instruments Inc. (USA, Fullerton 92634).

\section{Solutions}

Solution $1-3$ are taken from Merckotest No. 3307.

1. Colour reagent: 4,7-diphenyl-1,10-phenanthroline-disulfonic acid (bathophenanthroline, disodium salt, $0.68 \mathrm{mmol} / \mathrm{l}$ ) and sodium phosphate buffer $(0.4 \mathrm{~mol} / 1, \mathrm{pH}=5.5)$.

2. Sodium phosphate buffer $(0.4 \mathrm{~mol} / \mathrm{l}, \mathrm{pH}=5.5)$.

3. Working-Standard $\left(17.9 \mu \mathrm{mol} / 1 \mathrm{Fe}^{3+}\right)$.

4. Sodium ascorbate (part of Merckotest No. 3307):

$800 \mathrm{mg}$ sodium ascorbate $+20 \mathrm{ml} \mathrm{H}_{2} \mathrm{O}$ (must be prepared daily). 5. Stock binding reagent:

$500 \mathrm{mg} \mathrm{FeCl}{ }_{3} \cdot 6 \mathrm{H}_{2} \mathrm{O}$ (Merck No. 3943$)+\mathrm{HCl}(0.1 \mathrm{~mol} / \mathrm{l}$, Merck No. 9973) to $500 \mathrm{ml}$.

6 . Binding reagent:

Stock binding reagent $5 \mathrm{ml}+\mathrm{H}_{2} \mathrm{O}$ to $100 \mathrm{ml}$.

7. Magnesium carbonate:

$4 \mathrm{MgCO}_{3} \cdot \mathrm{Mg}(\mathrm{OH})_{2} \cdot \mathrm{nH}_{2} \mathrm{O}$ (Baker No. 0161) $1.5 \mathrm{~g}+5 \mathrm{ml}$ $\mathrm{H}_{2} \mathrm{O}$ (must be shaken before use). This sludge can be conveniently transferred with Eppendorf micropipettes if the $\mathrm{MgCO}_{3}$ is purchased from Baker.

8. Reference-standard (3):

a) Stock solution: a small piece (approx. $500 \mathrm{mg}$ ) of iron wire p. a. (Riedel de Haen, No. 31243) is dried until constant weight and added to $7 \mathrm{ml}$ conc. $\mathrm{HCl}$ (Merck No. 317) and $5 \mathrm{ml}$ double distilled $\mathrm{H}_{2} \mathrm{O}$. The container is placed in a boiling water until the wire is dissolved. The solution is then cooled to room temperature and brought to $500 \mathrm{ml}$ with double distilled $\mathrm{H}_{2} \mathrm{O}$.

b) Working solution: $5 \mathrm{ml}$ stock solution $+500 \mathrm{ml} \mathrm{HCl}$ ( $0.01 \mathrm{~mol} / \mathrm{l}$, Merck No. 9974$)+$ double distilled $\mathrm{H}_{2} \mathrm{O}$ to $1000 \mathrm{ml}$. 9. Titrisol-standard:

a) Stock solution: content of 1 vial Titrisol Eisen-Standardlösung (Merck No. 9972), $5 \mathrm{ml}$ conc. $\mathrm{HCl}$ (Merck No. 317) + double distilled $\mathrm{H}_{2} \mathrm{O}$ to $1000 \mathrm{ml}$.

b) Working solution: $89.5 \mu \mathrm{mol} / 1$.

$5 \mathrm{ml}$ stock solution, $2 \mathrm{ml}$ conc. $\mathrm{HCl}$ (Merck No. 317) + double distilled $\mathrm{H}_{2} \mathrm{O}$ to $1000 \mathrm{ml}$.

The iron concentration of the working solution determined at 10 days and referred to solution $8 \mathrm{~b}$ was $89.49 \mu \mathrm{mol} / \mathrm{l}$ ( $\mathrm{s}=1.35$ ). All further results were referred to the Titrisol-standard (9b) which was used to check the Merckotest-standard.

All solutions are prepared with deionized and quatz distilled water (approx. $0.5 \mu \mathrm{S}$ ). The glassware is washed in a standard machine, 


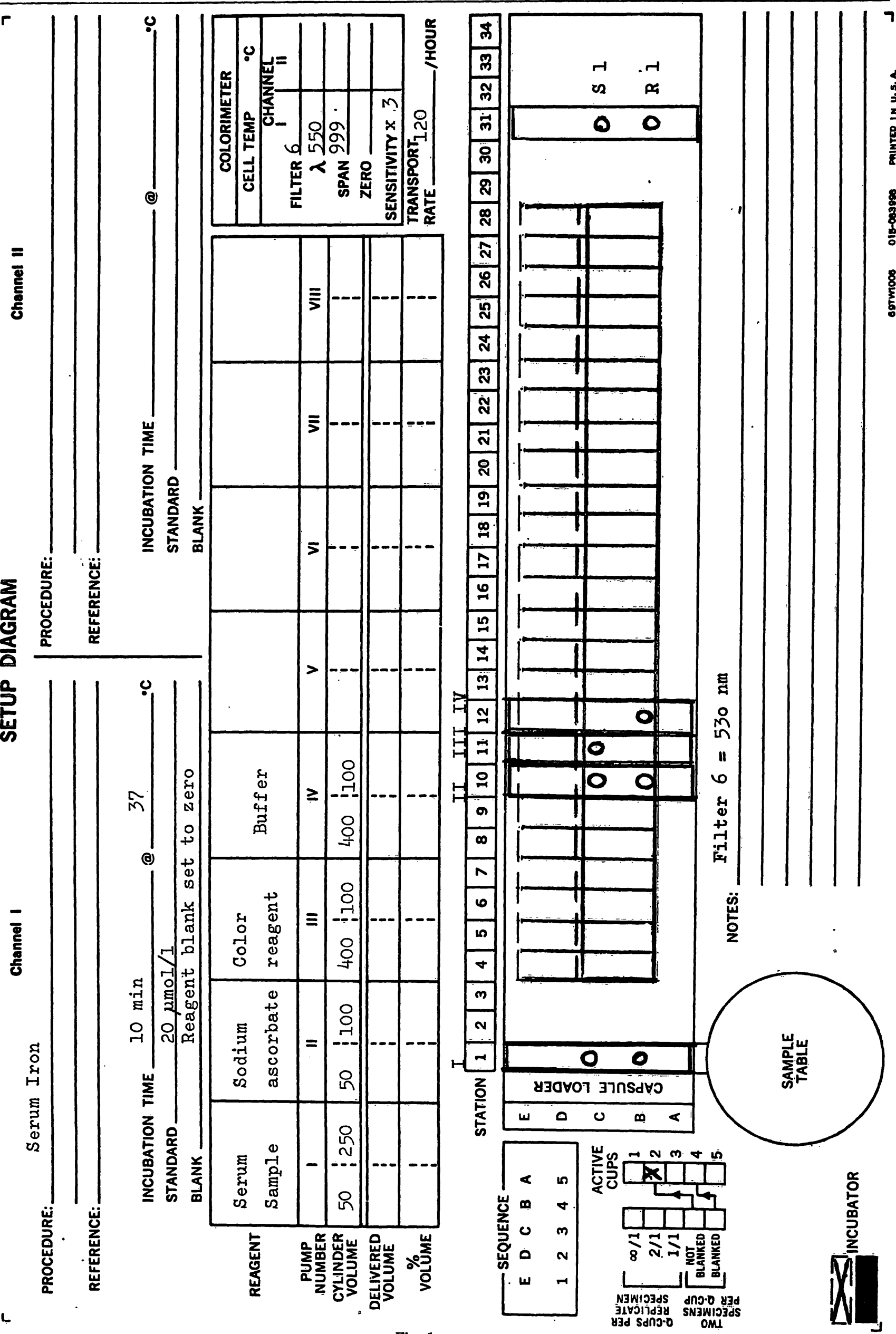

for the determination of the iron concentration 


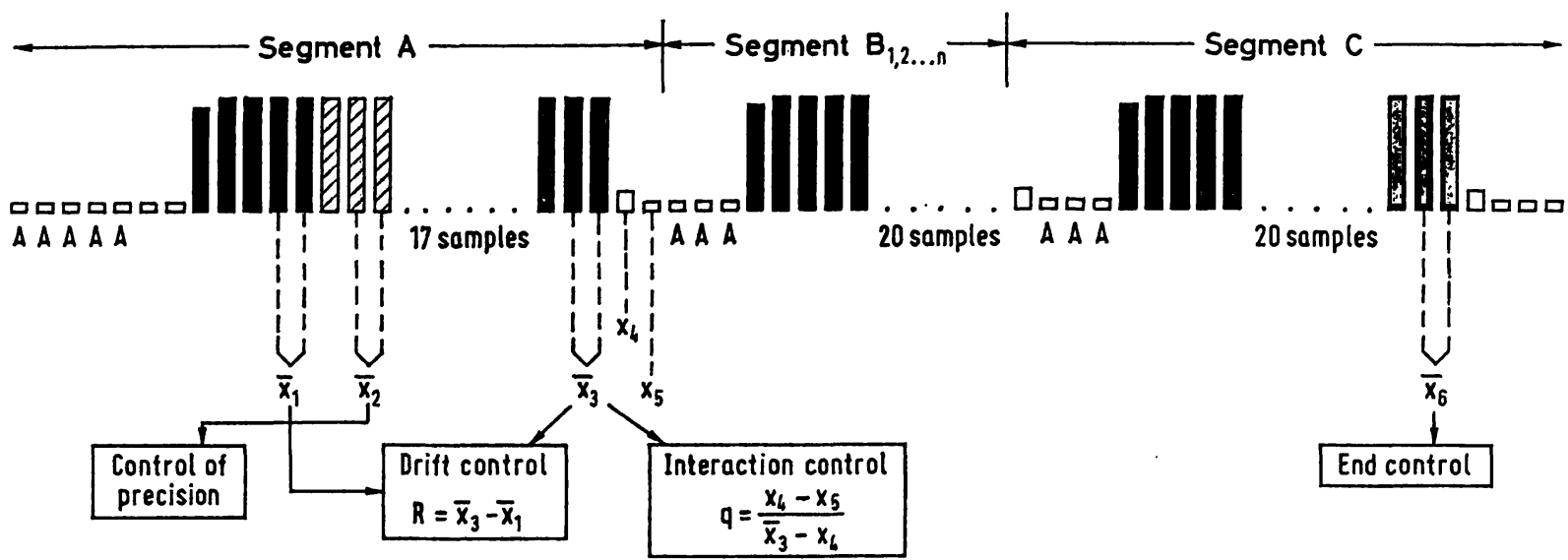

Fig. 2

The sequence of samples introduced into the DSA 560 for the determination of the iron concentration. The intersegment B can be repeated as often as required. A: the photometer is adjusted to give a zero printout

then soaked in concentrated $\mathrm{HCl}$ and rinsed carefully with double distilled $\mathrm{H}_{2} \mathrm{O}$.

Preparation of samples for the determination of the total iron binding capacity

Reaction cups are filled with Eppendorf micropipets:

$\begin{array}{ll}\text { Serum } & 200 \mu \mathrm{l} \\ \text { Solution (6) } & 200 \mu \mathrm{l}\end{array}$

Shake $1 \mathrm{~min}$ (Rotating mixer)

Let stand $5 \mathrm{~min}$

Solution (7) $\quad 400 \mu 1$

Shake $1 \mathrm{~min}$ (Rotating mixer)

Let stand $30 \mathrm{~min}$

Centrifuge $10 \mathrm{~min}$

The supernatant is analyzed for its total iron concentration. The result must be multiplied by 3.5 (dilution factor).

Each batch for the determination of iron binding capacity is started by 1 or 2 samples in which water is substituted for serum to check the adsorptive properties of $\mathrm{MgCO}_{3}$ : iron should not be detected in the supernatant of this blank assay.

The unbound iron binding capacity is determined according to SCHADE et al. (4) using Merckotest No. 3313.

\section{Determination of the iron concentration}

The iron concentration was determined directly in serum samples without deproteinization with the DSA 560 which is operated according to the instructions of the manufacturer. The set up of the analyzer is illustrated in Figure 1 and the sequence of samples in Figure 2. Reagent blank values usually drift parallel to the standard values and, therefore, need not be controlled separately. The primary standard $(17 \mu \mathrm{mol} / \mathrm{l})$ drifted about $+0.7 \%$ between 20 samples (=1 segment) at 27 days. Therefore, drift corrections are not necessary. The photometer readings are printed out and the final results are calculated using primary standards at the beginning of each segment.

The manual determination of the iron concentration was performed according to Schwartz (6) in trichloracetic acid extracts following the instructions of Merckotest No. 3307.

Transferrin was directly determined by a radial immunodiffusion technique using Partigen plates (Behringwerke AG, D-355 Marburg) according to MANCINI et al. (5).

For the determination of the precision 3 identical serum samples $\left(x_{\mathrm{a}}, \mathrm{x}_{\mathrm{b}}, \mathrm{x}_{\mathrm{c}}\right)$ are analyzed daily immediately following the standard solutions (Fig. 1): the precision within-series $\left(\mathrm{CV}_{\mathrm{s}}=\frac{100 \cdot \overline{\mathrm{x}}}{\mathrm{s}}\right)$ is calculated from the $x_{b}$-and $x_{c}$ values $\left(\bar{x}=\frac{\sum_{i=1}^{n}\left(x_{b 1}+x_{c 1}\right)}{2 m}\right.$; $\left.s=\sqrt{\frac{\sum_{i=1}^{n}\left(x_{b i}-x_{c i}\right)^{2}}{2 m}}\right)$, the precision from-day-to-day from the $x_{b}-$ (or the $\left.x_{c}\right)$ values

$$
\left(\overline{\mathbf{x}}=\frac{\sum_{i=1}^{n} x_{b 1}}{n} ; s=\sqrt{\frac{\sum_{i=1}^{n}\left(x_{b i}-\bar{x}_{b}\right)^{2}}{n-1}}\right) .
$$

Tab. 1

The precision of the determination of the total iron binding capacity and of the iron concentration

\begin{tabular}{|c|c|c|c|c|c|c|c|}
\hline & \multirow[t]{2}{*}{ Material } & \multicolumn{3}{|c|}{ Precision within-series } & \multicolumn{3}{|c|}{ Precision from-day-to-day } \\
\hline & & $\overline{\mathbf{x}}(\mu \mathrm{mol} / \mathrm{l})$ & $\mathbf{n}$ & $\mathrm{CV}_{\mathrm{s}}(\%)$ & $\overline{\mathbf{x}}(\mu \mathrm{mol} / \mathrm{l})$ & $\mathbf{n}$ & $c V_{d}(\%)$ \\
\hline \multirow{8}{*}[\mathrm{Fe}^{3+}]{} & Behring*), (Lot-No. 107 A) & 19.2 & (22) & 1.6 & 19.2 & (22) & 2.6 \\
\hline & Standard solution & 5.4 & (20) & 3.0 & & & \\
\hline & & 10.3 & (20) & 1.9 & & & \\
\hline & & 20.0 & (20) & 1.0 & & & \\
\hline & & 40.2 & (20) & 1.1 & & & \\
\hline & & 59.9 & (20) & 0.9 & & & \\
\hline & Standard solution + albumin $(70 \mathrm{~g} / \mathrm{l})$ & 14.9 & (15) & 1.0 & 15.0 & (15) & 4.3 \\
\hline & & 106.8 & (15) & 0.3 & 106.7 & (15) & 1.5 \\
\hline \multirow{4}{*}{$\begin{array}{l}\text { Total iron } \\
\text { binding } \\
\text { capacity }\end{array}$} & Pooled human serum & 73.4 & (10) & 2.1 & & & \\
\hline & & 67.8 & (18) & 2.4 & & & \\
\hline & Asid*), (Lot-No. OP_401) & 75,5 & (16) & 1.8 & & & \\
\hline & Behring*) (Lot-No. 107 A) & 76.4 & (18) & 1.6 & 76.4 & (18) & 2.8 \\
\hline
\end{tabular}

*) Control serum 


\section{Results and Discussion}

\section{Determination of the iron concentration}

The direct bathophenanthroline method of SCHWARTZ (6) was adapted to the DSA 560 and found precise enough for clinical routine determinations of the iron concentration in serum samples (Tab. 1). It correlated well with the manual procedure (Fig. 3) and was linear up to $200 \mu \mathrm{mol} / \mathrm{l} \mathrm{Fe}{ }^{3+}$ (Fig. 4). Different iron concentrations added to various human serum and urine samples were recovered within the $\pm 1 \%$ range (Tab. 2 ).

\section{Interaction effects}

Interaction effects are possible either at the sample pick up station or in the flow-through cuvet of the DSA 560. The first type of carry over could not be detected if a protein-containing sample (1) with $100 \mu \mathrm{mol} / 1$ iron was followed by a second one (2) with a pure albumin solution (Tab. 3). To discriminate between cross-contamination ${ }^{1}$ ) and carry-over effects

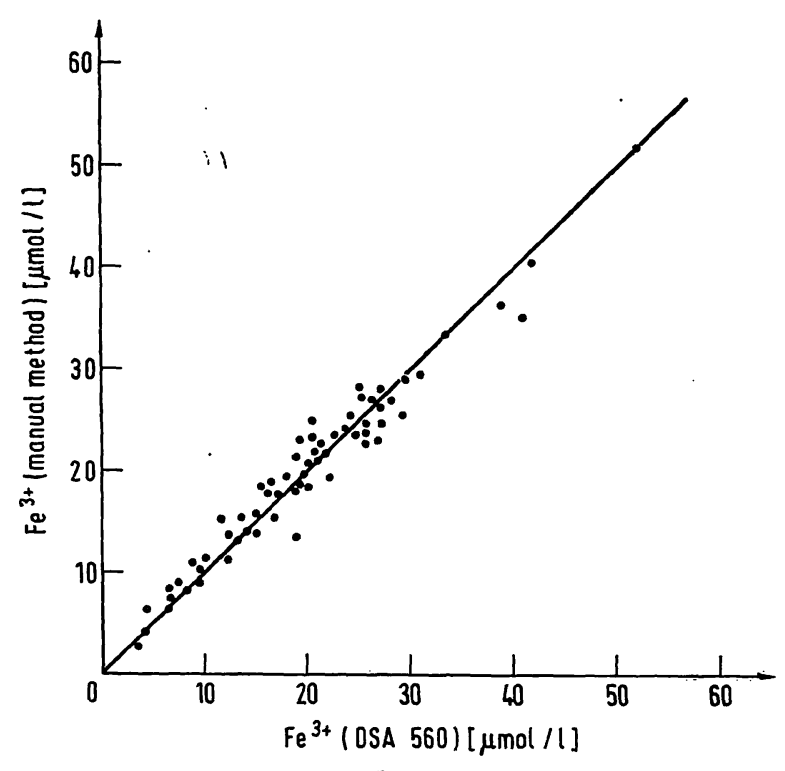

Correlation between a manual and the mechanized procedure for the determination of the iron concentration: $y=1.001 x-0.0552$,

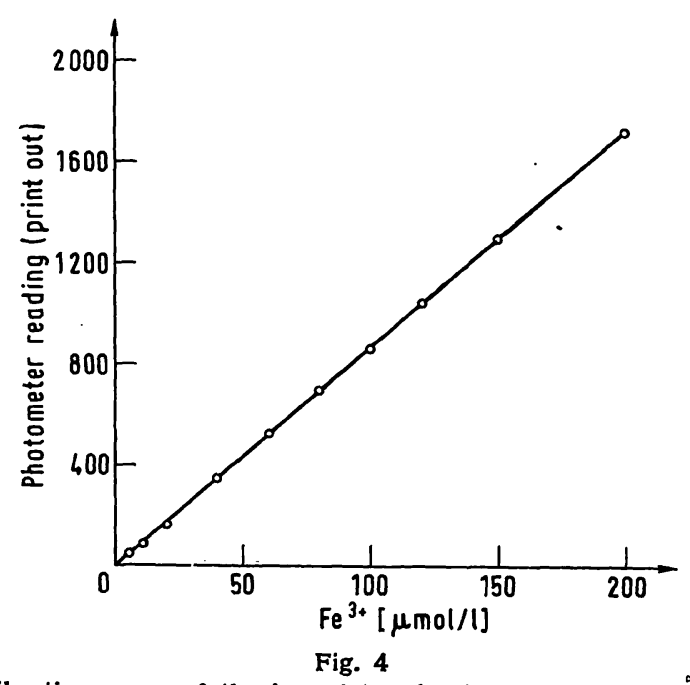

Calibration curve of the iron determination with the DSA 560

1) For explanation of the nomenclature see (1).
Tab. 2

Recovery of $\mathrm{Fe}^{3+}$ added to various human sera and urine samples

\begin{tabular}{rrrr}
\hline Sample & \multicolumn{2}{c}{$\left.\mathrm{FeCl}_{s}(\mu \mathrm{mol} /)^{*}\right)$} \\
found & $\begin{array}{c}\text { Recovery } \\
\%\end{array}$ \\
\hline Serum 1 & 16.3 & 16.5 & 101.2 \\
2 & 17.1 & 16.8 & 98.2 \\
3 & 17.8 & 18.1 & 101.7 \\
4 & 16.0 & 16.1 & 100.6 \\
5 & 17.8 & 18.11 & 101.7 \\
6 & 17.0 & 17.1 & 100.6 \\
7 & 16.4 & 16.5 & 100.6 \\
8 & 16.5 & 16.4 & 99.4 \\
& & & 98.8 \\
Urine & 16.1 & 15.9 & 100.6 \\
2 & 17.3 & 17.4 & 101.1 \\
3 & 17.4 & 17.6 & 99.4 \\
4 & 17.2 & 17.1 & 101.2 \\
5 & 16.7 & 16.9 & 100.0 \\
6 & 16.6 & 16.6 & \\
\hline
\end{tabular}

*) mean values from 2 determinations

Tab. 3

Cross-contamination between samples. Several Technicon cups (No. 127-0018) were filled with $1 \mathrm{ml}$ double distilled $\mathrm{H}_{2} \mathrm{O}$ (A) or albumin solution $(B, 70 \mathrm{~g} / \mathrm{l})$, No. 1 contained $\mathrm{FeCl}_{3}(100 \mu \mathrm{mol} / \mathrm{l})$ in addition. The pick-up tube dipped into the sample until it almost reached the bottom of the cups

\begin{tabular}{ccc}
\hline $\begin{array}{c}\text { Sample } \\
\text { No. }\end{array}$ & \multicolumn{2}{c}{ DSA 560 print-out } \\
\hline 1 & 0824 & B \\
\hline 2 & 0015 & 0851 \\
3 & 0003 & 0021 \\
4 & 0003 & 0008 \\
5 & 0001 & 0006 \\
6 & 0000 & 0007 \\
7 & 0000 & 0006 \\
8 & 0001 & 0006 \\
5 & 0000 & 0005 \\
2 & 0000 & 0005 \\
3 & 0001 & 0004 \\
4 & 0002 & 0005 \\
5 & 0002 & 0004 \\
10 & 0001 & 0005 \\
11 & 0005 & 0006 \\
12 & 0003 & 0004 \\
13 & 0003 & 0004 \\
\hline
\end{tabular}

which occur in the flow-through-cuvet system, sample (2) must be reanalyzed in a segment of blank samples containing no iron ions (Tab. 3).

A prerinsing concept with air bubbles segmenting the stream of the reaction mixture minimizes the interaction effects in the flow-through system of the DSA 560 photometer. The percent coefficient of interaction determined according to $\mathrm{HJELM}_{\text {(7) }}$ was $1.4 \%$ for $\mathrm{Q}_{1}$ and $\mathrm{Q}_{2}{ }^{1}$ ).

This value has to be considered in relation to the precision of the method. In a previous communication (8) we postulated that the error due to interaction effects should be less than the twofold or threefold value of the standard deviation determined in a batch with samples containing various concentrations of iron. From the figures in Table 1 and the $Q$ value reported above a tange can be calculated by means of equations derived recently (8), in which carry-over effects can be neglected (Fig. 5). It is assumed that $Q$ is independent 


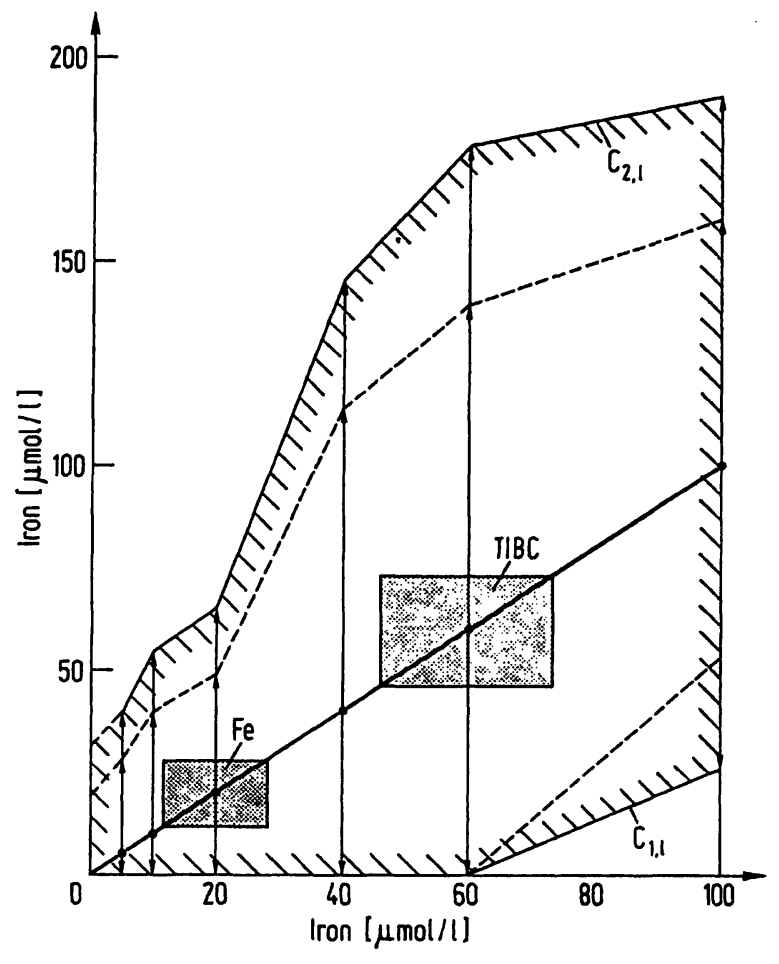

Fig. 5

The "interaction-safe range" (7) of the iron determination with the DSA 560. The concentrations forming this range are calculated according to (7): $C_{1,1}$ for the interaction from low to high concentrations an $C_{2,1}$ for the interaction from high to low concentrations. The stan$Q_{3}=1.39+0.58(n=20)$. It is postulated that the error due to $\mathrm{Q}_{3}=1.39 \pm 0.58(\mathrm{n}=20)$. It is postulated that the error due to dotted line) value of the within-series precision (standard deviation). $\mathrm{TIBC}=$ Total iron binding capacity

of the concentration difference between samples following each other as we have already shown for other procedures (8).

Figure 5 demonstrates that serious errors due to interaction effects are not be to expected with normal human sera. If a sample containing more than $40 \mu \mathrm{mol} / 1 \mathrm{Fe}^{3+}$ is followed by a second one with $5 \mu \mathrm{mol} / 1 \mathrm{Fe}^{3+}$ or less, the analysis of the last one has to be repeated because the error due to interaction effects exceeds the postulated limit of 3 standard deviations (Fig. 5).

Determination of the iron concentration in urine samples

According to several authors $(9,10)$ the direct bathophenanthroline method can also be used for urine samples. However, only elevated excretions of iron ions can be measured by this procedure, because the detection limit is about $0.3 \mu \mathrm{mol} / 1$ ( $\mathrm{n}=28$ days) as determined according to KAISER (11). The mean normal iron concentration of human urine is about $0.8 \mu \mathrm{mol} / 1$ (12).

\section{Interference}

Goodwin et al. (13) investigated the effect of lipemia, bilirubin and chelating agents as EDTA, DTPA (diethylenetriaminepentaacetic acid) and desferrioxamine without detecting any significant interference with the bathophenanthroline method. However, hemoglobin (13) and $\mathrm{Cu}^{2+}$ ions (10) elevate the results erroneously. The iron concentration of a standard with $17 \mu \mathrm{mol} / 1 \mathrm{Fe}^{3+}$ was found approximately $50 \%$ too high if the solution contained $90 \mu \mathrm{mol} / 1 \mathrm{Cu}^{2+}$ ions.

\section{Iron binding capacity}

The various methods mainly used for the determination of the serum transferrin concentration may be divided into 2 groups:

1. direct procedures using immunoprecipitation techniques $(5,14)$, and

2. indirect methods which measure the amount of iron bound to transferrin under saturating conditions (iron binding capacity). It is well known that 1 mole transferrin binds 2 moles $\mathrm{Fe}^{3+}$. These methods anticipate that all exogenous iron is bound exclusively to transferrin. Two ways are possible:

a) RAMSAY (2) precipitates the excess of iron with $\mathrm{MgCO}_{3}$ and determines all iron bound by the serum sample (total iron binding capacity). The free or unbound iron binding capacity is calculated by subtracting the iron concentration from the total iron binding capacity.

b) Conversely, the unbound iron binding capacity can also be measured directly either by colorimetric methods $(4,15)$ or by radiological procedures $(16-18)$.

Both procedures are compared with a direct immunological determination of transferrin (Fig. 6) using various human serum samples. In contrast to RENTSCH (19) the average value of the unbound iron binding capacity method was $10 \%$ lower than the mean transferrin-iron value indicating that the binding capacity was not fully saturated under these experimental conditions. With the total iron binding capacity procedure of RAMSAY we observed the highest mean vlaue for the iron binding capacity in agreement with several authors $(20-22)$, which have shown that besides transferrin other plasma proteins are able to bind iron ions. Therefore, the iron binding capacity value must be expected to exceed the transferrin-iron concentration in human sera. Indirect methods which yield iron binding capacity values lower than those determined with immunological procedures should be rejected.

Following these considerations we have chosen the method of RAMSAY, adapted it to the Eppendorf microliter system and the DSA 560 and reexamined the experimental conditions.

The value of the iron binding capacity increases with rising iron concentration (Fig. 7). This saturation curve is characterized by 2 points: a sharp bent at $50 \mu \mathrm{mol} / 1$ $\mathrm{Fe}^{3+}$ (assay concentration before the addition of $\mathrm{MgCO}_{3}$ ) and an upward bent at higher concentrations. The location of the second bent varied between 150 and $500 \mu \mathrm{mol} / \mathrm{l}$. Between both points a plateau is usually reached which is more or less flat. The first bent is presumably caused by the saturation of transferrin with iron, which is probably completed at a $\mathrm{Fe}^{3+}$ concentration of $90 \mu \mathrm{mol} / 1$. According to the curves shown in Figure 7 human serum samples should not be incubated with $\mathrm{Fe}^{3+}$ concentrations less than 50 or 


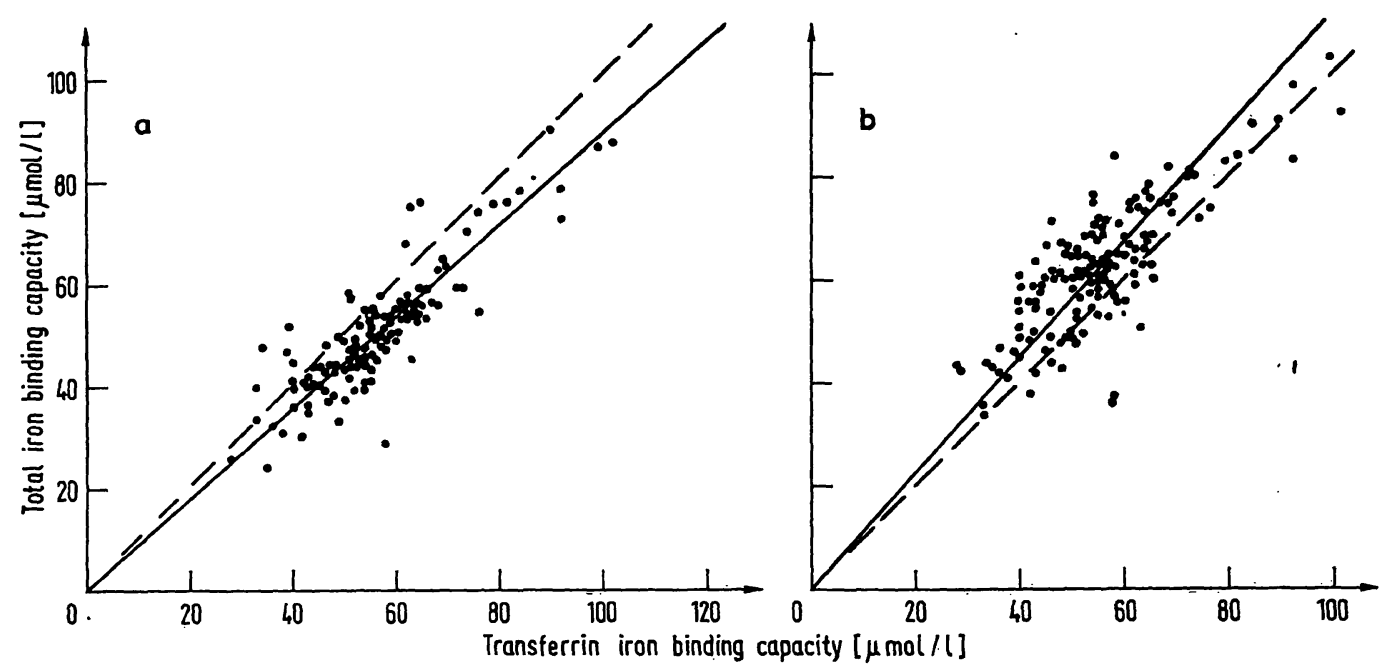

Fig. 6

Correlation between a direct immunological and an indirect colorimetric determination of the iron binding capacity. a) Unbound iron binding :capacity (manual procedure), $\mathrm{y}=0.8975 \mathrm{x}-0.0873, \mathrm{r}=0.99(\mathrm{~m}=120)$. $\mathrm{b})$ Total iron binding capacity $(\mathrm{DSA} 560), \mathrm{y}=1.1110 \mathrm{x}+$
$0.4692, \mathrm{r}=0.99(\mathrm{~m}=140)$. In both cases, $\mathrm{r}$ differs significantly from zero $(\mathrm{P}<0.001)$

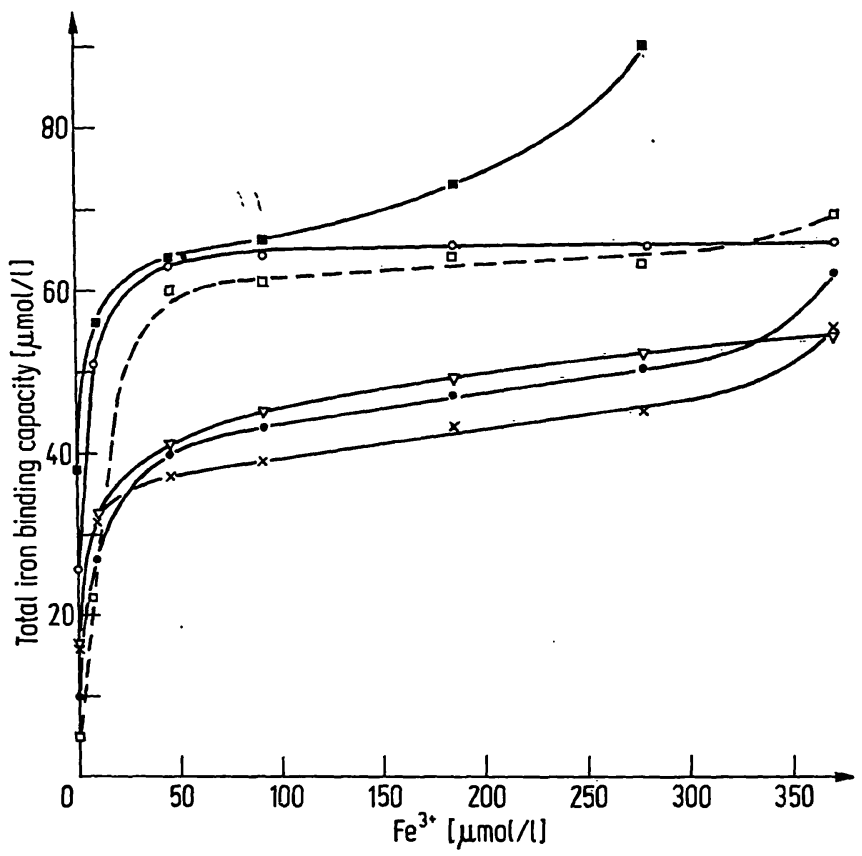

Fig. 7 The influence of the $\mathrm{Fe}^{3+}$ concentration $(200 \mu \mathrm{l}$ serum $+200 \mu \mathrm{l}$
$\mathrm{FeCl}_{3}$ solution) on the total iron binding capacity of six human sera

more than $100 \mu \mathrm{mol} / \mathrm{l}$. If the serum was substituted by double distilled $\mathrm{H}_{2} \mathrm{O}$ even a concentration of $1000 \mu \mathrm{mol} / \mathrm{l}$ $\mathrm{Fe}^{3+}$ was competely absorbed. Control sera which must be reconstituted have different patterns of the saturation curve as will be demonstrated in a following report.

An incubation time of $5 \mathrm{~min}$ is found sufficient for the binding of $\mathrm{FeCl}_{3}$ to transferrin. After the addition of

Tab. 4

The influence of the incubation time (between addition of $\mathrm{MgCO}$ and centrifugation) on the adsorptive power of $\mathrm{MgCO}_{3}$. The figures are mean values from 10 various human serum samples (range: $32-62 \mu \mathrm{mol} / \mathrm{l})$

\begin{tabular}{lccccc}
\hline $\begin{array}{l}\text { Incubation time } \\
\text { (minutes) }\end{array}$ & 1 & 5 & 10 & 30 &, 60 \\
$\begin{array}{l}\text { Total iron binding } \\
\text { capacity }(\mu \mathrm{mol} / \mathrm{l})\end{array}$ & 45.3 & 45.7 & 46.4 & 43.8 & 44.0 \\
\hline
\end{tabular}

$\mathrm{MgCO}_{3}$ we prefer to wait $30 \mathrm{~min}$ (Tab. 4) until the samples are centrifuged, in agreement with GoodwIN et al. (13).

However, this incubation time appears not to be critical (Tab. 4). The addition of sodium barbital as suggested by WILliams and Conrad (23) is not necessary, since serum has enough buffering capacity to guarantee an alkaline $\mathrm{pH}$.

Enough $\mathrm{MgCO}_{3}$ (120 mg/assay) is added as determined from Figure 8. When $\mathrm{MgCO}_{3}$ was formed from $\mathrm{Mg}^{2+}$ and $\mathrm{CO}_{3}^{2-}$ ions as proposed by FRIED and HoEFLMAYR (24) the saturation point cannot clearly be defined with pooled human serum (Fig. 9).

Under these experimental conditions the from-day-today precision of the determination of total iron binding capacity with the DSA 560 was $2.8 \%$ (Tab. 1 ).

In conclusion, the mechanized procedure for the measurement of iron binding capacity as reported above is reliable enough for clinical purposes. In agreement with SCuRo et al. (21) the author suggests that a differentiation is made between transferrin iron-

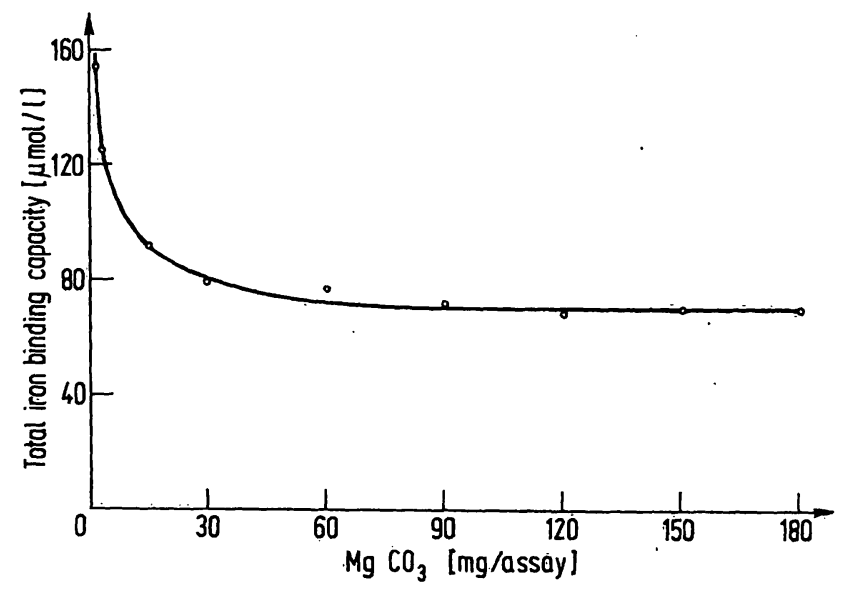

Fig. 8

The relationship between the total iron binding capacity of pooled human serum and the $\mathrm{MgCO}$ concentration used to precipitate the 


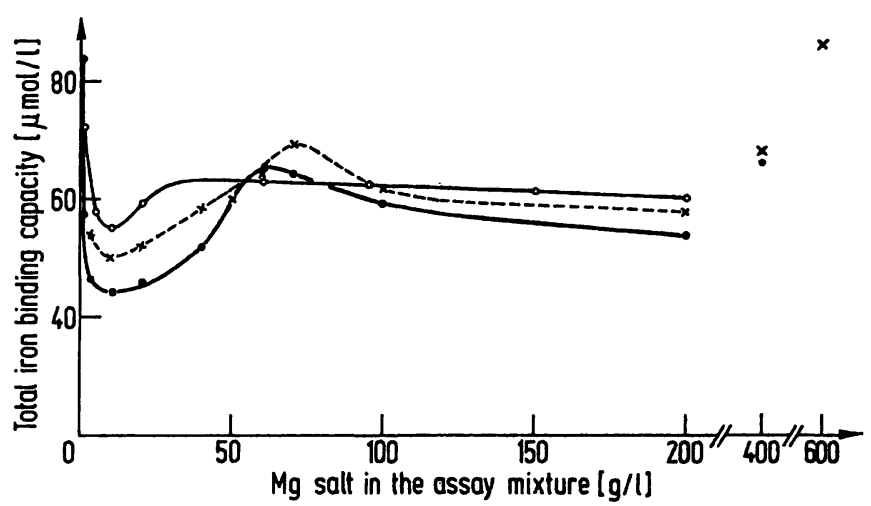

Fig. 9

The influence of the $\mathrm{Mg}^{2+}$ concentration on the total iron binding capacity if free $\mathrm{Fe}^{3+}$ ions are bound by $\mathrm{MgCO}$, in statu nascendi Assay conditions: $O---0200 \mu 1$ pooled serum, $400 \mu 1 \mathrm{MgCl}_{2}$. $6 \mathrm{H}_{2} \mathrm{O}+\mathrm{FeCl}_{3} \cdot 6 \mathrm{H}_{3} \mathrm{O}(24,2 \mathrm{mg} / \mathrm{l}), 200 \mu \mathrm{l} \mathrm{Na}_{2} \mathrm{CO}_{3}$ (water free, $200 \mathrm{~g} / \mathrm{l}) ; \times--\times, 0_{-}-0_{200 \mu 1}$ pooled serum, $400 \mu 1$ $\mathrm{MgSO}_{1} \cdot 7 \mathrm{H}_{2} \mathrm{O}+\mathrm{FeCl}_{3} \cdot 6 \mathrm{H}_{2} \mathrm{O}(48 \mathrm{mg} / \mathrm{l}), 200 \mu \mathrm{l} \mathrm{Na} \mathrm{CO}_{2} \cdot 10 \mathrm{H}_{2} \mathrm{O}$ The conditions of incubation, centrifugation and determination of the iron concentration in the supernatant with the DSA 560 are the same as reported under methods

binding capacity and total iron-binding capactiy. The discrepancy between both values "as an index of extra-transferrin iron transport" (21) has to be further evaluated with respect to its clinical significance. The total iron binding capacity is a very relative term which can be used only under the conditions represented by the "plateau part" of the saturation curve (Fig. 7).

Various authors $(25,26)$ reported that storage of serum leads to higher iron values with the direct bathophenanthroline method. Under our experimental conditions
Tab. 5

The influence of storage $\left(4^{\circ} \mathrm{C}\right)$ on the iron concentration $(\mu \mathrm{mol} / \mathrm{l})$ and the total iron binding capacity $(\mu \mathrm{mol} / \mathrm{l})$ of various human sera. Each value is a mean of 2 determinations

\begin{tabular}{|c|c|c|c|c|c|c|}
\hline \multicolumn{2}{|c|}{ Storage, days } & 0 & 1 & 2 & 3 & 4 \\
\hline \multicolumn{7}{|c|}{ A. Iron concentration } \\
\hline \multirow{10}{*}{ Sample } & 1 & 18.3 & 18.8 & 18.1 & 18.1 & 18.2 \\
\hline & 2 & 12.6 & 14.1 & 13.1 & 12.1 & 13.1 \\
\hline & 3 & 11.8 & 13.6 & 12.6 & 12.2 & 12.9 \\
\hline & 4 & 12.7 & 14.4 & 13.6 & 12.5 & 13.3 \\
\hline & 5 & 11.8 & 12.7 & 12.0 & 11.9 & 12.6 \\
\hline & 6 & 12.2 & 13.3 & 12.5 & 11.6 & 12.2 \\
\hline & 7 & 21.8 & 22.8 & 22.6 & 21.6 & 22.4 \\
\hline & 8 & 19.5 & 21.1 & 20.6 & 19.3 & 20.7 \\
\hline & 9 & 4.0 & 5.0 & 5.0 & 4.5 & 5.0 \\
\hline & 10 & 8.5 & 10.2 & 9.3 & 8.2 & 8.8 \\
\hline \multicolumn{2}{|c|}{ Mean value } & 13.3 & 14.6 & 13.9 & 13.2 & 13.9 \\
\hline \multicolumn{7}{|c|}{ B. Total iron binding capacity } \\
\hline \multirow[t]{11}{*}{ Sample } & 1 & 39 & 38 & 42 & 39 & 40 \\
\hline & 2 & 78 & 76 & 80 & 77 & 78 \\
\hline & 3 & 68 & 67 & 71 & 67 & 69 \\
\hline & 4 & 32 & 29 & 35 & 31 & 30 \\
\hline & 5 & 57 & 57 & 60 & 63 & 54 \\
\hline & 6 & 50 & 52 & 50 & 47 & 44 \\
\hline & 7 & 44 & 44 & 43 & 40 & 38 \\
\hline & 8 & 51 & 53 & 53 & 48 & 47 \\
\hline & 9 & 47 & 49 & 48 & 42 & 46 \\
\hline & 10 & 48 & 50 & 48 & 45 & 45 \\
\hline & Mean value & 51 & 52 & 53 & 50 & 49 \\
\hline
\end{tabular}

the iron concentration and the total iron binding capacity (Tab. 5) of human sera did not change for at least 3 days if the samples were kept at $4^{\circ} \mathrm{C}$.

\section{Literatur}

1. HAECKel, R. (1972), this journal 10, 235-242. - 2. RAMSAY, W. N. M. (1953), Biochem. J. 53, 227-231. - 3. BотнWвLL, T. H., Conrad, M. E., Cook, J. D., Crosby, W. H., Fielding, J., Hallberg, L., Izak, G., Layrisse, M. \& Ramsay, W. N. M. (1971), J. Clin. Path. 24, 334 -335. - 4. Schade, A. C., Oyama, J., Reinhart, R. W. \& Miller, J. R. (1954), Proc. Soc. Exp. Biol. Med. 87, 443-448. - 5. Mancini, E., Carbonara, A. O. \& Heremans, J. F. (1965), Immunochemistry 2, 235-240. - 6. Schwartz, D. E. (1957), Bull. Schweiz. Vereinig-Klin. Chem. 1, 1. - 7. HJELM, M. (1968), Z. Anal. Chem. 243, 781-790. 8. HAeckel, R. \& Porthi, A. J. (1972), this journal 10, 91-94. 9. KunEsh, J. P. \& Smait, L. L. (1970), Clin. Chem. 16, 148-149. 10. Konne, A. (1970), Z. Inn. Med. 25, 125-127. - 11. KaISER, H. (1965), Z. Anal. Chem. 209, 1-18. - 12. Plötner, K. \& Petzel, H. (1954), Klin. Wochenschr. 32, 821-822. - 13. Goodwin, J. F., Murphy, B. \& Guillemetre, M. (1966), Clin. Chem. 12, 47-57. - 14. JAGER, B. V. \& Guber, J. (1952), J.
Immunol. 69, 311-315. - 15. Persijn, J. R., VAN DeR SilK, W. \& RIEThorst, A. (1971), Clin. Chim. Acta 35, 91-98. - 16. FiniNstein, A. R., Bethard, W. F. \& McCarthy, J. D. (1953), J. Lab. Clin. Med. 42, 907-914. - 17. Horst, W. \& SCHÄFER, K. H. (1953), Klin. Wochenschr. 31, 340-341. - 18. EICKENBUSCH, W. \& LAHRTZ, H. (1969), Ärztl. Lab. 15, 12-20. - 19. ReNTsCH, I, (1969), Klin. Wochenschr. 47, 433-437. - 20. STOJCESKI, T. K., Malpas, J. S. \& Witts, L. J. (1965), J. Clin. Path. 18, 446-452. - 21. Scuro, L. A., Dobrilla, G., Lo Cascio, V., Bosello, O., D'Andrea, F. \& Junesco, A. (1972), Acta Hep. Gastroent. 19, 90-98. - 22. vaN DER Heul, C., van EiJK, H. G., Wiltink, W. F. \& Leijnse, B. (1972), Clin. Chim. Acta 38, 347-353. - 23. Williams, H. L. \& ConRad, M. E. (1972), Clin. Chim. Acta 37, 131-140. - 24. Fried, F. \& Hoeflmayr, J. (1954), Klin. Wochenschr. 42, 645. - 25. Hoeflmayr, J. \& Fried, R. (1966), Med. Klinik 61, 1820-1823. - 26. Bonitz, K. (1968), this journal $6,501-502$.
Priv. Doz. Dr. R. Haeckel 3000 Hannover Karl-Wiechert-Allee 9 